Ansell N, Robson E, Hajdu F and van Blerk L (2012) 'The spatial construction of young people's livelihoods in rural southern Africa' Geography 97(3) 135-140

\title{
The spatial construction of young people's livelihoods in rural southern Africa
}

Nicola Ansell (Centre for Human Geography, Brunel University, Uxbridge, UK)

Lorraine van Blerk (Geography, University of Dundee, Dundee, UK)

Elsbeth Robson (Centre for Human Geography, Brunel University, Uxbridge, UK / Department of Anthropology, Durham University, UK)

Flora Hajdu (Department of Urban and Rural Development, Swedish University of Agricultural Sciences, Uppsala, Sweden)

\begin{abstract}
Young people in southern Africa, in common with young people around the world, are social agents, constructing their lives, albeit within significant structural constraints. Unlike young people in some regions, for most the need to generate a livelihood is a key consideration. Livelihood construction is a profoundly spatial activity, yet while there have been a number of studies of the spatial construction of young people's livelihoods in African cities, the spatiality of rural livelihoods has received less attention. Rural environments pose particular challenges for livelihood construction, and require particular spatial strategies. Four are discussed here: accessing education and training; migration for work; developing extensive social networks; and producing for markets. There are, however, aspects of the spatial structuring of rural southern African societies that seriously constrain the pursuit of productive livelihoods. Two are considered: migration (for reasons unconnected with young people's livelihoods) and marriage practices.
\end{abstract}

Within the field of children's geographies, it has become a truism that young people are social agents, actively involved in shaping their own lives. While for young people in Western societies, this usually means that they exercise some control over their relationships with family and peers, and a degree of choice in their pursuit of leisure and sometimes educational activities, for young people in Africa, livelihood activities represent a further important realm for the exercise of agency. While we should be careful not to exaggerate the extent of young people's agency in regions where structural conditions demand that young people undertake productive and reproductive work, there is a growing literature that examines the ways in which young Africans construct livelihoods for themselves. Children work to support their families, by contributing to the agricultural and domestic work of the household (Robson 1996; Robson et al 2006), as entrepreneurs in marketplaces (Abebe and Kjorholt 2009), and in informal or more formal employment (Bourdillon 2000), often making significant contributions to household income (Jaiyebo 2003). They take decisions for themselves, sometimes in conjunction with others, and shaped by family expectations and changing structural conditions (Awumbila and Ardayfio-Schandorf 2008; Katz 2004). In some contexts, such as southern Ethiopia, structural circumstances are such that whereas in the past, families worked together, today children's livelihood participation is increasingly independent of adults (Abebe 2007). 
Ansell N, Robson E, Hajdu F and van Blerk L (2012) 'The spatial construction of young people's livelihoods in rural southern Africa' Geography 97(3) 135-140

This paper explores the role of spatiality in young people's construction of their livelihoods. Human geographers increasingly understand the social and spatial to be co-constructed (Massey 2005). The spatialities that shape and constrain society - infrastructures, city and regional plans, patterns of migration, diversities in levels of investment - are outcomes of social, economic and political processes. At the same time, all aspects of social (and economic) life are inevitably spatially structured - the spatial organisation of society determines what is or is not possible or likely. Thus, as geographers, we must understand livelihoods to be constructed from the spatially structured resources that individuals or groups can access.

There has been some research on the ways in which young people use spatial strategies in producing livelihoods within African cities. For instance, van Blerk (2005) examines how street children in Uganda make use of different urban niches (e.g. market places, minibus taxi parks) in order to support themselves; Abebe (2008) similarly charts Ethiopian street children's spatial strategies, as they move between the city centre, commercial districts and transport hubs and congregate in mosques and churches where alms are offered at certain times. Langevang (2008) and Langevang and Gough (2009) have shown how out-of-school youth move around Accra, Ghana, in a quest for livelihood opportunities. Less common is research on young people's spatial engagements with rural environments in the construction of livelihoods.

Young people need to engage with the spatial structures of their societies and economies and do so by adopting spatial strategies. However, the spatial structuring of society can also pose barriers to the construction of successful livelihoods that are not necessarily easily overcome. Rural environments in southern Africa represent a challenge to livelihood construction, as the resources required to build a livelihood are often spatially dispersed, and require significant effort to secure access. This paper explores four key ways in which rural young people use spatial strategies to construct rural livelihoods, but also examines two aspects of the spatial structuring of society and economy that stand in the way of their pursuit of secure and productive livelihoods. It does so by drawing on the findings of several research projects conducted with young people in Lesotho and Malawi over the past 16 years. These projects examined the impacts of education on rural girls' empowerment (fieldwork in Lesotho, 1996 and 1997; see Ansell 2002); children's migration as a response to the AIDS pandemic (fieldwork in Lesotho and Malawi, 2001; see Ansell and van Blerk 2004) and the impacts of AIDS on rural young people's livelihoods (fieldwork in Malawi and Lesotho, 2007 and 2008; see Hajdu et al 2011). All three projects used combinations of primarily qualitative methods, including semi-structured interviews and focus groups, as well as more childrencentred activities including, for example, writing, drawing, photography and drama. Key locations are mapped in Figure 1.

Figure 1 about here

\section{Accessing education and skills}

There is a popular belief among young people in many southern African societies that formal education offers the key to lucrative livelihoods. This belief does not necessarily reflect the realities that face most school leavers: even those who obtain qualifications are seldom able to find the employment they desire (Ansell 2002; Chant and Jones 2005). However, the belief persists, and most young people aspire to remain in school as long as possible, and complete their secondary education. Given that schools (especially secondary schools) in rural environments usually have geographically extensive catchments (reflecting generally low population densities and low levels of school enrolment), it is common to travel long distances to gain an education. To attend secondary school, it may 
Ansell N, Robson E, Hajdu F and van Blerk L (2012) 'The spatial construction of young people's livelihoods in rural southern Africa' Geography 97(3) 135-140

be necessary to board - either formally in boarding school hostels, or informal 'self-boarding' by staying with relatives, renting rooms or 'bush boarding' which involves young people (almost exclusively boys) constructing temporary accommodation for themselves close to the school.

Mahloko ${ }^{1}$ High School in Lesotho's Maluti Mountains serves a very sparsely populated region. While several of the students walked two hours each way, through the rugged mountain landscape, in 1996 most of the 240 students lived too far away to be able to walk. Around 150 of the younger of these children stayed in hostels run by the nuns at the Roman Catholic mission about a mile away, where they were required to provide their own bedding, cooking and laundry equipment and to shop and cook for themselves. The older students rented rooms together in the nearby village. On the last Friday of each month, school closed early and most of the students made their way, usually by bus, back to their villages to collect money and food for the coming month.

Obtaining vocational training in rural areas can be even more problematic. Few African governments expend the resources on vocational education that they devote to conventional schooling, and rural youth wishing to train in a skill not practised within their own household usually have to travel to specialist centres or find individuals willing to teach them. Tumelo (aged 22 when he was interviewed in 2008), left his village for three weeks during one school holiday and stayed in Maseru (Lesotho's capital city) where he learned coffin-making from a carpenter who plied his trade on a city street, a skill Tumelo was later able to employ to generate an income in a remote village.

Young people's efforts to secure a future livelihood through education and training thus required them to engage in considerable spatial mobility, negotiating rugged terrain on foot and/or by public transport and spending considerable periods at a distance from their homes. They do so with little direct involvement or supervision from their parents or other adults, beyond the delivery of the academic or vocational education itself. This situation reflects the spatial organisation of African education, which is influenced by economic constraints (limiting, for instance, the provision of educational establishments) and cultural expectations that young people are able to take responsibility for their own day-to-day wellbeing.

\section{Migration for work}

While the immediate rural environment might offer some livelihood opportunities (boys in Lesotho, for instance, can usually find work herding cattle for people in their own or a neighbouring village), pressure on available agricultural land is such that it is seldom possible for young people to generate a livelihood in this way. In Lesotho in particular, it is unusual to be allocated farmland prior to marriage. If young people want to earn an income, rather than simply assist their parents, they often need to seek work elsewhere. In Malawi, Emily (aged 21) had migrated several times during her childhood. As she explained:

E: [W] hen I was 10 a vehicle came looking for people to work in town, so I went in that group.

I: What were they going to do in town?

E: To mould bricks and maybe fetch water

\footnotetext{
${ }^{1}$ Pseudonyms are used for the school and individuals.
} 
Ansell N, Robson E, Hajdu F and van Blerk L (2012) 'The spatial construction of young people's livelihoods in rural southern Africa' Geography 97(3) 135-140

Her father had died she and her brother were recruited, along with others from the village, and spent 6 months making bricks in a township of Blantyre (Malawi's largest city). She returned to the village, but shortly afterwards a neighbour found her another opening in a different Blantyre township where she worked as a cook for 2 years. She left this job because she thought she was too poorly paid, and a friend found her work as a cook in a different township. Being away from home can make young people vulnerable, and Emily, in common with several other female research participants, left this job to avoid being sexually exploited by her employer. Mussa (aged 18), from the same village, worked as watchman in Lilongwe (Malawi's capital city, nearly $400 \mathrm{~km}$ away) and Zomba (a nearby town), as a garden boy in Blantyre, and on the macadamia plantations in Nasoniya, all before the age of 15 (see Figure 2). He then started school, but soon gave up and returned to Zomba district as a fisherman, and then went to neighbouring Mozambique in search of work, returning to the village at the age of 20. While an extreme example, this illustrates how young people's livelihoods are often shaped by opportunities for migration.

Figure 2 about here

\section{Using dispersed social networks}

For young people without formal educational qualifications, social networks are crucial to livelihood prospects (Chant and Jones 2005). This is particularly clear in some of the examples above, where young people were able to make use of their social networks to build livelihoods based on migration. In southern Africa it is not unusual for social networks to be spatially extensive: a long history of labour migration has fractured families, created new connections, and migration is now built into the social fabric. To learn new skills, find employment or have somewhere to stay while studying or searching for opportunities in town, young people cultivate and make use of long-distance relationships. Milka (aged 21), for instance was found work in Lilongwe by her sister's friend and in Blantyre by a friend of her grandparents. Wilson (aged 19), also from Malawi, planned to launch a fish-trading business, and expected relatives to accommodate him when he travelled to purchase fish.

I: Are there people you are to stay with in Limbe or you are going to operate from here?

W: We will stay there.

I: At whose place?

W: There is my other uncle; he is at Limbe market. And in Zomba as well there is my aunt.

In the past, social relationships were best sustained through travelling and meeting with people in person, but today it is increasingly common for young people to have access to mobile phones: they might not own one, but there is commonly someone in the village who can send and receive text messages on their behalf. Sesotho speakers resident in Johannesburg commonly call acquaintances in Lesotho villages in order to recruit domestic workers, as rural girls are considered less troublesome than those to be found in the cities. It seems likely that the growing use of mobile phones will mean that extensive social networks play an even greater role in the future for young people seeking to construct livelihoods in rural areas. 
Ansell N, Robson E, Hajdu F and van Blerk L (2012) 'The spatial construction of young people's livelihoods in rural southern Africa' Geography 97(3) 135-140

\section{Producing for markets}

Few young people find employment that can provide a secure livelihood. While there may be possibilities of casual work for neighbours, this is seldom regular or well paid. In southern Malawi, some young people find work on agricultural plantations, but this too is very poorly paid, seasonal and not very secure. Domestic work, too, is problematic. Hence for many young people, a livelihood is best secured by producing commodities for sale, or selling a service such as building or repair work. Such activities, however, depend on an adequate market: a pool of sufficient people with sufficient resources to sell the goods or services to.

In some rural areas, markets are simply too small. In the Maluti Mountain village mentioned above, there are few opportunities for young people to market goods or even services. Ironically, the village is well connected to the city so South African imported food and other goods are available either locally (a small 'supermarket' two hours walk away) or by travelling to town in person (an hour's walk plus a three hour bus ride). Tumelo, for instance, found his coffin-making skills more marketable in a more remote village, where the dead could not be transported to urban mortuaries, but needed to be buried quickly. As he explained: 'the fact is those places are far from the roads so when they have the deceased they don't take them to the mortuary, they just bury them the following $d a y^{\prime}$. This avoided the costly transport of a coffin from elsewhere, and provided Tumelo with a captive market.

In the Malawian study village, by contrast, there were several large market places within an hour or two's walk or cycle ride. As a consequence, young people found it worthwhile to invest time and effort in growing vegetables that they 'irrigated' using watering cans, or cooking snack foods for sale. Others were able to make a living by trading: buying in relative bulk at the markets and selling in the village or at other markets.

These examples illustrate how young people respond to the spatial contingencies of their environments through spatial practices that in general allow them to construct a livelihood. There are some spatialities of southern African societies, however, that serve as obstacles to productive livelihoods. Two of these are briefly outlined below.

\section{Migration and disruption}

As mentioned above, migration is written into the social fabric in southern Africa. While young people choose to migrate in order to find opportunities, some young people have to migrate for other reasons, and this may disrupt their livelihood activities, and cause them difficulties. Elsewhere (Ansell and van Blerk 2004) we have discussed the ways in which southern Africa's AIDS pandemic is resulting in children migrating between extended family households - either when their parents or guardians become sick or die, or more often where their household is affected by loss of income or increased costs associated with sickness or death. Such migration can have significant effects on young people. Unusually for migration in African settings, AIDS-related children's migration is often from urban to rural areas, as families return to their villages when adults become sick or unable to work, or because children are sent to be cared for by rural grandparents. Such children, in particular, are often ill-equipped to participate in commonplace livelihood activities. Migrant boys in Lesotho talked of how, when new to village life, they lacked herding skills that other boys had acquired from infancy. They would allow the cattle to wander onto farmers' fields, for which they would be punished. Thabo (aged 15) drew a picture (Figure 3) to illustrate his experience:

Figure 3 about here 
Ansell N, Robson E, Hajdu F and van Blerk L (2012) 'The spatial construction of young people's livelihoods in rural southern Africa' Geography 97(3) 135-140

In Rodrigue, this is my uncle beating me because I had been looking after the cattle and sheep and they had eaten the crops belonging to someone else ... This was the first time I had been herding, so I didn't know that was wrong.

Migration also disrupts education, many young migrants lacking the paperwork to transfer to new schools, or being moved back a class or two because schools teach different curricula or use a different language. Such youth may be propelled from education into fulltime economic activity. Migration also disrupts the social networks that are so valuable in providing livelihood opportunities (although it can also contribute to creating more extensive networks). In the longer term, young people who are incomers to rural communities are less likely than their more settled peers to inherit land and productive assets that would enable them to pursue a successful rural livelihood.

\section{Marriage and disruption}

A particular form of migration is that associated with marriage. Across southern Africa, most societies are exogamous: young people generally marry outside their immediate communities, usually in their late teens (although the requirement to pay bridewealth leaves few young Basotho men able to marry before their late 20s). Inevitably, then, marriage entails migration for at least one party. In Lesotho, as in most parts of the region, young women move to their husbands' homes when they are married. By contrast, in southern Malawi, it is young men who move to join their wives. This migration can impose limitations on livelihood activities. In southern Malawi, in fact, contact is initially maintained with both villages: the woman moves to her husband's village for perhaps a year until the couple have built a house in her village. This allows the husband to maintain the social networks on which his livelihood might rely, while building new networks. Nonetheless, some young married men, once resident in their wives' villages reported that it was difficult to find work. Rex (aged 27), for instance, who had previously worked as a housebuilder, found his services were passed over in favour of locally-born youths, who were better known and perhaps better trusted. He explained: 'you know these days if one has work he tells his relations. Even if I try to show my skill some still prefer their relatives'.

Young women in Lesotho experienced a more abrupt transition when they married; most had not previously visited their new village and their move would be permanent. For them, marriage meant not only a disruption to social networks that might have provided livelihood opportunities. It also brought with it an expectation that they would remain resident in their new village, and not migrate in search of better opportunities. Often their education was brought sharply to an end, and along with this their aspirations for the future. Many young women in Lesotho described marriage as their greatest disappointment in life.

\section{Conclusions}

In conclusion, young rural southern Africans strive to construct livelihoods in environments where both economic conditions and social practices are spatially structured in ways that require particular types of response. Young people adopt one or more of a range of spatial strategies in order to ensure more productive or secure livelihoods. Often these 'strategies' are responses to opportunities that arise; few have the luxury to choose between alternative options. Significantly, both the spatial strategies young people adopt and the livelihood opportunities available to them are strongly shaped by gender relations that are constructed differently in different places. 
Ansell N, Robson E, Hajdu F and van Blerk L (2012) 'The spatial construction of young people's livelihoods in rural southern Africa' Geography 97(3) 135-140

Moreover, the spatial structuring of society (itself gendered) also serves to constrain livelihood opportunities for many.

\section{References}

Abebe T 2007 'Changing livelihoods, changing childhoods: patterns of children's work in rural southern Ethiopia' Children's Geographies 5(1-2) 7-93

Abebe T 2008 'Earning a living on the margins: begging, street work and the socio-spatial experiences of children in Addis Ababa' Geografiska Annaler 90(3) 271-284

Abebe T and Kjorholt AT 2009 'Social actors and victims of exploitation: working children in the cash economy of Ethiopia's South' Childhood 16(2) 175-194

Ansell N 2002 "Of course we must be equal, but ...': imagining gendered futures in two rural southern African secondary schools' Geoforum 33(2) 179-194

Ansell N and van Blerk L 2004 'Children's migration as a household/family strategy: coping with AIDS in southern Africa' Journal of Southern African Studies 30(3) 673-690

Awumbila M and Ardayfio-Schandorf E 2008 'Gendered poverty, migration and livelihood strategies of female porters in Accra, Ghana' Norwegian Journal of Geography 62(3) 171-179

Bourdillon M (ed) 2000 Earning a life: working children in Zimbabwe Weaver Press, Harare

Chant S and Jones G 2005 'Youth, gender and livelihoods in West Africa: perspectives from Ghana and the Gambia' Children's Geographies 3(2) 185-199

Hajdu F, Ansell N, Robson E, van Blerk L and Chipeta L (2011) 'Income-generating activities for young people in southern Africa: Exploring AIDS and other constraints' Geographical Journal 177(3) 251-263

Jaiyebo O 2003 'Women and household sustenance: changing livelihoods and survival strategies in the peri-urban areas of Ibadan' Environment and Urbanization 15(1) 111-120

Katz C 2004 Growing up global: economic restructuring and children's everyday lives University of Minnesota Press, Minneapolis

Langevang T and Gough KV 2009 'Surviving through movement: the mobility of urban youth in Ghana' Social and Cultural Geography 10(7) 741-756

Langevang T 2008 'Claiming place: the production of young men's street meeting places in Accra, Ghana' Geografiska Annaler: Series B, Human Geography 90(3) 227-242

Massey D 2005 For space, Sage, London

Robson E 1996 'Working girls and boys: Children's contributions to household survival in West Africa' Geography 81(353) 403-407 
Ansell N, Robson E, Hajdu F and van Blerk L (2012) 'The spatial construction of young people's livelihoods in rural southern Africa' Geography 97(3) 135-140

Robson E, Ansell N, Huber US, Gould WTS and van Blerk L 2006 'Young caregivers in the context of the HIV/AIDS pandemic in Sub-Saharan Africa' Population, Space and Place 12(2) 93-111

van Blerk L 2005 'Negotiating spatial identities: mobile perspectives on street life in Uganda' Children's Geographies 3(1) 5-21 
Ansell N, Robson E, Hajdu F and van Blerk L (2012) 'The spatial construction of young people's livelihoods in rural southern Africa' Geography 97(3) 135-140

Figure captions:

Figure 1: Key research locations: Nihelo in Malawi and Ha Rantelali in Lesotho

Figure 2: Mussa's life map, illustrating his work-related migration

Figure 3: Thabo's picture of his punishment 